\title{
RAIMONDA SIMANAITIENE்
}

Vytauto Didžiojo universitetas, Lietuva

Vytautas Magnus University, Lithuania

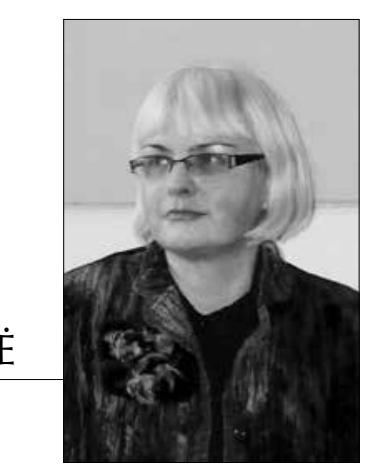

\section{ŽODŽIO IR VAIZDO GALIA MARIJONOS SINKEVIČIENĖS TEKSTILE்JE

\author{
The Power of Word and Image in the Textile \\ by Marijona Sinkevičienè
}

\begin{abstract}
SUMMARY
Textile artist Marijona Sinkevičienè is known as a longtime lecturer at the Faculty of Arts and Education of Kaunas Collegium, and a participant of numerous exhibitions in Lithuania and abroad. The artist focuses on creation of artworks for exhibitions. The most notable among them are the latest artworks among which are the series of tapestries, portraying sacral and Lithuanian history subjects. The characteristic feature of the artist's creative process is her personal outlook, her focus on text insertions and the language of symbols. Extraordinary awareness and individual understanding of materials and techniques that the artist employs facilitates the specific shaping and the highly suggestive and esthetic plasticity of the artworks.
\end{abstract}

\section{SANTRAUKA}

Tekstilès dailininkė Marijona Sinkevičienė žinoma kaip ilgametė Kauno kolegijos Menų ir ugdymo fakulteto dėstytoja, daugelio parodų Lietuvoje ir užsienyje dalyvè. Menininkè daugiausia kuria parodinius darbus. Iš jų labiausiai išsiskiria paskutiniųjų metų gobelenų ir tapiserijų serijos, atspindinčios sakralumo ir tautos istorijos tematiką. Šioms klasikinėms, mene gana dažnai pasitaikančioms temoms j̨amžinti pasitelkiamas asmeninis požiūris, teksto intarpai, simbolių kalba. M. Sinkevičienès tekstilès darbams būdingas ypatingas medžiagiškumo ir technikų išmanymas, išryškinantis autorès kūrinių plastikos įtaigumą ir estetiką.

\section{IVADAS}

Dailininkę Marijoną Sinkevičienę ne- $\quad \mathrm{ku}$, kurie XX a. pabaigoje-XXI a. praabejotinai galime priskirti prie meninin- džioje paskatino atsinaujinti ir koncep- 
tualèti Lietuvos tekstilę. Šiandien šią tekstilininkę vertiname kaip išraiškingo, individualaus braižo kūrèją lakoniškos, santūrios, o kartu vaizdiškai itin įtaigios plastikos darbų autorę, sakralinio paveldo ir istoriniu tautiniu vertybiu puoselètoją. Žvelgdami i M. Sinkevičienès kūrybos panoramą matome jos nuolatini sieki eksperimentuoti, ieškoti savitos tematikos ir autorinès technikos. Ir nors menininkès darbai yra gerai žinomi Lietuvos tekstilès kontekste, tačiau išsames- nio menotyrinio aptarimo ar detalesnès apžvalgos jie nėra sulaukę. Minètos priežastys paskatino M. Sinkevičienès kūrybą analizuoti nuodugniau. Straipsnyje norèta pristatyti tekstilininkès asmenybę, išryškinti jos kūriniuose vyraujančias temas ir išskirti esmingiausius plastinius bruožus. Dailininkès darbai vertinti istorinëje perspektyvoje, nagrinèti naudojantis semantinès ir formaliosios analizės prieigomis. Tyrimas papildytas interviu metu išsakytomis dailininkės mintimis.

\section{KŪRYBINĖS BIOGRAFIJOS ŠTRICHAI}

Marijona gimè $1951 \mathrm{~m}$. Žemaitijoje, Tauragès rajone, Očikiu kaime. Daile ji susidomëjo dar būdama mergaitè, kai gyveno ir mokèsi netoli Raseinių esančiu Nemakščiu mokykloje. Paskatinta klasės auklètojos Birutès Miliauskaitės $1967 \mathrm{~m}$. istojo ị tuometini Kauno Stepo Žuko taikomosios dailès technikumą, čia igijo rūbu modeliuotojos specialybę. Neilgai padirbusi aprangos dizainere buitinio aptarnavimo kombinate Marijampoleje, menininkè vèl grįžo į Kauną ir mokslus tęsė LTRS valstybinio dailès instituto Kauno vakariniame skyriuje, kur 1976$1982 \mathrm{~m}$. studijavo tekstilę (Draugelienè 2003: 412-413). Menininkè teigè, kad i šią specialybę stojo apsisprendusi tobulèti: turèdama rūbu modeliuotojos išsilavinimą jau gerai nusimanè apie tekstilès technologijas, audinius, o studijuojant tekstilę šios žinios dar labiau prasiplètè. Anot M. Sinkevičienès, rūbų dizainerès ir tekstilininkès patirtys susiliejo itin sèkmingai, nes puikiai papildè viena kitą. Institute jai dèstè žinomi menininkai - Zenonas Varnauskas, Marija Dūdienè, Dalia Valatkienè. Vis dèlto turbūt didžiausią itaką jau- najai dailininkei padarė Z. Varnauskas, kurio žodis buvo ypač svarus vertinant kūrinius, komentuojant pasaulinius meno pavyzdžius, vadovaujant diplominiam darbui ${ }^{1}$. Nemažai profesiniu patarimų paskaitose suteikdavo ir M. Dūdienè. Akivaizdu, kad desstytoja taip pat vertino savo buvusią studentę. Rekomenduodama Marijoną stoti i Dailininkų sajunga, tekstilininkè rašè, kad ji „pasižymëjo labai rimtu požiūriu ir kūrybingumu vykdant kursines kompozicijos užduotis“2.

Tekstilès studijas M. Sinkevičienè baigè 1982 m. ir itin greitai įsiliejo į tuometinių žymesnių ir ką tik pradejjusių kurti tekstilininku gretas (Mažrimienè 2011: 144-145). Kaune tuo metu telkèsi dailininkès Jūratė Petruškevičienè, Zita Mateiča, Liucija Šepkutė-Banaitienė, Birutè Sarapienė, Virginija Kirvelienė. Šios menininkès pamažu èmèsi vis įdomesniu kūrybinių užsakymų, parodinių darbų. $\mathrm{Su}$ ju vardais Kaune vèliau buvo siejamas ir tekstilès meno sujudimas, kuri ypač suaktyvino netrukus issitraukusi ir kiek jaunesnè dailininkẻ Laima Oržekauskiené ir jos mokiniu karta. 


\section{ANKSTYVŲJŲ KŪRINIŲ MENINIAI BRUOŽAI}

Kūrybinio kelio pradžioje M. Sinkevičienė nuaudè nemažai gobelenų ir tapiserijų. Jau ankstyvieji jos darbai buvo pastebèti: vienas pirmuju stambesnių kūrinių ("Architektūriniai motyvai“, 1983) pažymètas Kultūros ministerijos ir eksponuotas Pabaltijo taikomojo meno trienalèje ${ }^{3}$. Šis, i ritmiškas struktūras padalintas gobelenas tarsi paženklino dailininkès kelią, atskleidè jos kompozicinę samprata, kurią apibrèžè formu aiškumas, griežtumas, jausmo ir logikos harmonija, kolorito gelmè.

$X X$ a. antroje pusèje pamažu vis modernëjanti Lietuvos tekstilè devintajame dešimtmetyje neabejotinai turèjo savus skiriamuosius bruožus (Rekertaitè-Načiulienė, Stelingienė 1983: 6-7). Kūriniuose vis dažniau išryškèdavo struktūriška kompozicinè traktuote, ritmiškos vaizdo jungtys, audinio faktūringumas, dekoratyvumas, figūrinius motyvus keitẻ abstrakčios formos. Minètas savybes galëjome išvysti Zinaidos Vogelienès, Jūratès Urbienès, Salvinijos Giedrimienès, Felikso Jakubausko, Violetos Laužonytės ir kitų menininkų darbuose (Mačiulis 2003: 248-250). M. Sinkevičienè taip pat prisidejo prie novatoriškus plastinius sprendimus demonstruojančio tekstilès autoriu būrio. Šiuo laikotarpiu ji èmèsi eksperimentuoti formatais ir kurti skaidytas kompozicijas, kurias buvo galima įvairiai perkomponuoti. Tokiu pavyzdžiu galime laikyti gobeleną „Ilgesys“ (1994), sudarytą iš keturių nevienodų apimčių audinio elementu. Šis kūrinys gali būti eksponuojamas keliais skirtingais būdais: audinio gabalus dèliojant vertikaliai, horizontaliai arba skirtingais kampais ir taip kaskart sukurti vis naują vizualų objektą. Ir nors žvelgdami i š ši kūrini pirmiausia ji siejame su modernizmo praktika (abstraktumu, konstruktyvumu ar minimalizmu), labiau issigilinę matome, kad tai kur kas gilesnę prasmę turintis darbas, igyvendintas permąstant lietuvišku raštų ornamentuose ryškèjančias liaudies meno patirtis.

Kitas žinomas dailininkès ankstyvosios kūrybos pavyzdys - tapiserija "Gimtinè“, sukurta 1993 m. Žvelgdami ị šio rusvos gamos triptiko motyvus galime patirti įvairias vizijas: regèti gimtinę menančių laukų panoramas, „čiurlioniškus" vartus, močiučiu išsiuvinètus audinius ar net Gediminaičiu stulpų elementus. Vis dèlto visi šie motyvai triptike yra išreikšti itin lakoniškai, užuominomis, asociatyviai. Beje, nuo jaunumès pamègusi austi serijomis, ši iproti menininke išsaugojo iki pastarujų dienų.

Tai, kad ankstyvojoje kūryboje M. Sinkevičienè itin saikingai vartojo teminius motyvus, nebuvo atsitiktinumas. Menininkè ne kartą teigè, kad tekstileje jai svarbu „kalbèti“ pačia medžiaga, audiniu, faktūra, "per siūlą išreikšti mintį" (Simanaitienè 1996: 168). Jos kūriniuose atsispindèjo pasąmonès, nuojautų ir nuotaikų raiška, perteikiama kūrinio ritmu, ornamentu ar koloritu. Simbolinės, kontrastingos spalvos traktuotos kaip gèrio ir blogio, šviesos ir tamsos priešpriešos. Jausmu ekspresiją mateme juodai raudonų, žaliai baltu, juodai pilkų darbu gamoje (triptikas „Formos kitimas“, 1997). Užklupusių minčiu ar trapių nuotaiku greitesni fiksavimai vyko dailininkei pasirinkus mini formatą - tekstilès žanra, 
kai i̇manoma tarsi vienu atokvėpiu išreikšti savo vidinę būseną („Langas“, 1983). XX a. paskutiniais dešimtmečiais mini tekstilè Lietuvoje buvo ypač populiari: rengtos mini tekstilès parodos, simpoziumai (Meilūnienè 2018: 24). Dèl galimybių eksperimentuoti dailininkè aktyviai issitraukè $i$ ši judejjimą. Taip radosi kūriniai, kuriuose dominavo erdvinès formos, šalia tradicinių audinių (vilnos, lino) pasitelktos sintetinès medžiagos.
Beje, sintetinių medžiagų (dažniausiai polietileno) panaudojimas iš mažojo formato darbų palaipsniui persikèlè ir į monumentalias erdvines instaliacijas, kurias M. Sinkevičienė sukūrè pačioje $X X$ a. pabaigoje-XXI a. pradžioje (,Žiemos prisiminimai“, 1997; "Dienoraštis I, II, III“, 1999; „Vyšnių sodas“, 2006). Šioms instaliacijoms būdingas skaidrumas, efemeriškumas, lengvumas dailininkès kūrybą praturtino naujais atspalviais.

\section{KŪRYBINĖS BRANDOS IR SAKRALUMO ŽENKLAI}

Atgavus Lietuvai nepriklausomybę, nemažai menininkų èmėsi dar vieno tekstilès žanro - vèliavų, susijusių su bažnyčios, draugiju ar instituciju poreikiais. I ši būri įsitraukè ir M. Sinkevičienè. Anot menininkès, vèliavą padaryti nèra taip paprasta: reikia mokèti ją pasiūti, dekoruoti, žiūrèti, kad medžiaga gerai kristų, o tai - sudètingas, profesionalaus išmanymo reikalingas procesas ${ }^{4}$. 1992 m. pagal dailininko Arvydo Každailio projektą M. Sinkevičienė sukūrè Vilniaus miesto didžiąą vèliavą. Vèliau, 1996-2000 m., sukūrè Lietuvos krikščionių demokratų, Žąslių miestelio, Kauno prekybos ir pramonès mokyklos, Utenos kolegijos vèliavas. Jos padarytos pasitelkiant siuvimo, aplikavimo, siuvinejjimo technikas, i̇sigilinus ị heraldikos keliamus reikalavimus. Tarp menininkès sukurtú vèliavu galima pamatyti ne tik politinėms partijoms ar miestams skirtų darbų. Viena įspūdingiausių yra Laptevų jūros tremtinių brolijos vėliava (2001), kurios centre pavaizduotas ledinès Sibiro pakrantès simbolis - baltasis lokys, o už jo išsiuvinèti kryžiai, skirti negrižu- siųjų iš atšiaurių kraštų atminčiai. Vèliavai panaudotas mèlynas audinys, primenantis Šiaurès dangų ir vandeni, šalti ir ledini sąstingi.

Pastarajị dešimtmeti $M$. Sinkevičienès kūryba buvo susijusi su keliais įdomiais tiriamaisiais projektais, kurie iš esmès inspiravo menininkę kurti ir dalyvauti tęstinèse parodose.

2008 m. buvo pradètas rengti projektas „Keliaujančios raidès “5. Nors kiekvienais metais šio projekto koncepcija buvo formuluojama iš naujo, tačiau tikslas išlikdavo vis toks pats - rašto meno puoselëjimas ir jo sklaida. Prie „Keliaujančių raidžių“" projekto prisidejusi M. Sinkevičienė sukūrè darbų ciklą su išaustais tekstais. Ilgainiui itterpti tekstą $\mathfrak{i}$ audini tapo vienu iš šiuolaikinių menininkès kūrybinių principų.

2008 m. bendradarbiaudama su Raseinių krašto istorijos muziejumi èmèsi projekto „Kultūros paveldas - sakralinè tekstile““. Pasak menininkès, jo tikslas buvo surinkti ir išsaugoti jau nykstančią bažnytinę dailę. Buvo surengta tiriamoji ekspedicija Raseinių krašte, kurios me- 
tu peržiūrèti bažnyčiu archyvai, senuju liturginių drabužių, vèliavų, užtiesalų kolekcijos. Raseinių rajonas ekspedicijai buvo pasirinktas neatsitiktinai: pati užaugusi šiose vietovėse $M$. Sinkevičienè norèjo atlikti savojo regiono tautinio paveldo ir bažnytinių objektų tyrimą. Menininkè pasakojo, kad sakralinè tekstilè ją domino seniai, nuo mažu dienų visada „buvo skaudu matyti, kaip po truputị iš bažnyčiu pranyksta ar yra naikinami autentiški audiniai, kurie laikui bėgant dažniausiai tiesiog pakeičiami naujais sintetiniais. Būtent todèl pradèta galvoti apie sakralinių audinių išsaugojimą ir naujų sukūrimą ${ }^{\mu 6}$.

Projekto metu „lankydami bažnyčias, labiausiai atkreipème dėmesị i tekstilès dirbinius, puošiančius bažnyčių altorius, per bažnytines iškilmes nešamas vèliavas, liturginius drabužius. Žavejo turtinga menine raiška igyvendinti siuvinèjimai, nėriniai, audiniai, jų raštai. Tai patys kilniausi, nuoširdžiausi, su meile atlikti ir sukurti darbai. Tačiau bėgantys metai, negailestingas laikas paliečia viską. Žmonès, kurie atliko šiuos darbus, išeina i
Amžinybę, laipsniškai išnyksta ir jų darbai. Norètųsi prikelti, užfiksuoti, pažymèti, palikti ateinančioms kartoms tai, kas dar yra, kad jaunoji karta, pasimokiusi, pasisėmusi patirties, galètu kaip estafetę perduoti kitiems“" (Servienè 2014).

Inspiruota pamatyto bažnytinio paveldo $M$. Sinkevičienè nusprendè išausti sakralines prasmes ir simbolius telkiančiu kūrinių ciklą ir jị pademonstruoti autorineje tekstilès parodoje „Prikelta i būtì". Kiekviename iš šios serijos darbu galëjome išvysti senujų sakralinių audiniu parafrazes: išsiuvinètas teksto nuorodas i citatas iš Šventojo Rašto, spalvų ir medžiagu pasirinkima, lyginantis $\mathfrak{i}$ anksčiau meistru naudotus audinius. Anot M. Sinkevičienès, „Prikelta į būtį" buvo tokia paroda, kuri atrode tarsi surinkta iš kokių nors bažnytinių archyvų. Dirbant čia taikyta ypatinga siuvinẻjimo technologija, leidžianti žvelgti i abi kūrinio puses kaip i pagrindines. Darbuose dominuojančios spalvos (žalia, violetinè, raudona) sietos su liturginemis šventèmis, kaip ir visa ornamentika: vynuogès, tulpès, lelijos ${ }^{7}$.

\section{APMĄSTANT TAUTOS ISTORIJĄ}

Paskutiniuju metu M. Sinkevičienès kūrybinę veiklą ryškiausiai ịprasmino dar vienas projektas - Lietuvos valstybingumo 100-mečiui skirta paroda "Atmintis" (2018), kurią sudare jau aptartos tekstilès parodos „Prikelta į būtį" ir naujų kūrinių, skirtų Lietuvos jubiliejui paminèti, dermè. Šią ekspoziciją pati dailininkè vertino kaip sieki iprasminti Lietuvos istorinę atminti, norą pademonstruoti tautos kelią ir ryžtą išsaugo- jant globalias vertybes, atspindint tautiškumą ir tikejjimą. Parodoje demonstruoti patriotinès tematikos darbai. Visuose kūriniuose svarbų vaidmenį atliko audinyje išsiuvinèti tekstai: skanduotės (,Lietuva, būk laisva“, ,Leiskit į tévynę, leiskit pas savus"), citatos iš partizanu dainu, trijų Baltijos šalių valstybiu vardai, tèvynei skirti eilèraščiai. Tarkime, viename iš parodos kūrinių buvo išsiuvinètos poeto Maironio eilèraščio „Lie- 
tuva brangi“ eilès: „Graži tu, mano brangi tèvyne, šalis, kur miega kapuos didvyriai." Šiuos žodžius tekstilès darbuose papildė Lietuvoje simbolines reikšmes turintys austiniai motyvai, pavyzdžiui, tvirtybès medžio ąžuolo lapai, gilès. Tekstilès triptike "Baltijos tautų kelias" (2017) matėme ne tik lietuvių, latvių ir estų kalbomis įrašytus šalių pavadinimus, bet ir kiekviename iš trijų darbų išsiuvinètus tos šalies liaudies raštus bei vèliavas.

2018 m. parodą "Atmintis“ menininkė eksponavo įvairių miestų galerijose. Vienaip ji atrodè Vilniaus rotušeje ir visaip kitaip - Kaune, „Meno parko“ ga- lerijoje. Čia autorè pasitelkè nepaprastai ìspūdingą apšvietimą. Visi kūriniai buvo demonstruojami apšviesti neoninès šviesos. Žiūrovas ì mèlynai baltus darbus žvelgè tamsoje, naujai patirdamas apšviestų kūrinių keliamas emocijas. Dèl neoninių šviesu teikiamo efekto buvo matomi visi tekstilès ataudai, kurie yra nepastebimi esant ịprastam apšvietimui. Išryškinti švytintys žodžiai ir simboliai tarsi igavo naują itin sakralią prasmę. Taigi pasitelkiant šiuolaikines technologijas bei sprendimus (eksponavimo galimybes, neonines šviesas), parodos eksponatai igijo ypatinga vizualuma, dvasinguma, konceptualumą.

\section{EPILOGAS}

Apibendrinant M. Sinkevičienės meninę raišką galima teigti, kad jos tekstilèje nauju formu paieškos skleidèsi nuo pat kūrybinio kelio pradžios. Dailininkès ankstyvųjų gobelenų meninis stilius buvo novatoriškas laiko atžvilgiu - jam būdingas konstruktyvumas, minimalizmas, abstraktumas. Kai kuriuose kūriniuose atsispindèjo saikingas lietuvių liaudies motyvų interpretavimas, mini tekstileje reiškèsi formų plastiškumas, erdviniai sprendimai, medžiaginiai eksperimentai. Pamažu menininkès kūryba evoliucionavo į kur kas konceptualesni tarpsni, paremtą tiriamaja projektine veikla. Taip

\section{Literatūra}

Draugelienė Dalia (sud.). 2003. Kauno dailininkai. Pédsakai laike: albumas. Kaunas: Kauno dailininku paramos fondas.

Meilūnienė Jūratė (sud.). 2018. Taikomoji dailè ir dizainas 1918-2018: albumas. Vilnius: Lietuvos dailès muziejus. radosi serijos darbu, kuriuose apmąstytas tautos paveldas, ivertinta istorijos ir sakralinio meno reikšmè. Šiuose kūriniuose išryškejjo teksto svarba, simbolinių teminių motyvų poveikis. Semantiškai pagrįstas kūrinių koloritas. Per projektus sukurtuose darbuose drąsiai derintos įvairios medžiagos, technikos, apšvietimas. Pasitelktas audimas, aplikacija ir siuvinejjimas ì neoninę šviesą reaguojančiais baltos medvilnès siūlais menininkei leido sukurti efektingus, įtaigius parodinius sprendimus, praplečiančius kūrinių vizualią charakteristika, o kartu turtinančius ir žiūrovo suvokimo lauką.

Simanaitienè Raimonda. 1996. Taikomoji daile ir dizainas. Marijona Sinkevičiene. Kauno menininkai: albumas. Kaunas: Kauno meno fondas.

Rekertaitè-Načiulienė Daiva, Stelingienè Silverija (sud.). 1983. Lietuvos gobelenas: albumas. Vilnius: Vaga. 
Mačiulis Algimantas. 2003. Dailè architektūroje. Vilnius: Vilniaus dailès akademijos leidykla.

Mažrimienė Vida (sud.). 2011. Kauno dailè: realijos en face: albumas. Kaunas: Nacionalinis M. K. Čiurliono dailès muziejus.

\section{Nuorodos}

1 Jaunai studentei ypač įsiminè tai, kaip dėstytojo pakviesta $\mathfrak{i}$ jo dirbtuvę galèdavo susipažinti su sovietmečiu sunkiai gaunamais meno albumais, japonų tekstilès pavyzdžiais. Iš pokalbio su dailininke. 201912 12. Kaunas.

2 Marijos Dūdienès rekomendacija priimant M. Sinkevičienę i LDS narių gretas. 1988. Archyviniai duomenys iš Marijonos Sinkevičienès bylos. Lietuvos dailininkų sąjungos Kauno skyrius.

3 Tuometinejje Sovietų sąjungoje ši paroda laikyta itin modernia, patekti i ją buvo galima tik praejus rimtą atranką.
Servienè, Aurelija. 201406 05. Prikeltas tautos sakralinis menas. Telšiu žinios. http://tzinios.lt/ prikeltas-tautos-sakralinis-menas/ [žiūrèta 2019 12 14]

4 Iš pokalbio su dailininke. 201912 12. Kaunas.

5 Šis projektas sutelkè izvairių sričių menininkus, buvo plètojamas kasmet pasitelkiant skirtingas potemes.

6 Iš pokalbio su dailininke. 201912 12. Kaunas.

7 Menininkè, kaip labai tikintis žmogus, nuolatos gilinosi i katalikiškas bažnytines tradicijas ir apeigas. Iš pokalbio su dailininke. 20191212. Kaunas. 